\title{
ČLÁNKY
}

\section{Testing for Housing Discrimination in the United States}

\author{
Michael P. Seng*
}

\begin{abstract}
Testing is necessary to ensure the effective enforcement of the anti-discrimination laws. Discrimination in housing is rarely overt. Testing is often the only means available to show that a housing provider was motivated by discrimination. Testing can rebut claims that the housing was unavailable and can show that similarly situated applicants were treated differently or given false information because of their protected status. Testers who are treated differently suffer damage, and they should be awarded damages similar to those awarded bona fide complainants.
\end{abstract}

\section{Keywords}

Civil Rights; Housing; Discrimination; Testing; Damage.

\section{The Problem - How does one detect discrimination?}

In a case decided in December 2015, the District Court of Litomerice found that a real estate agent violated the Czech Anti-Discrimination Act and the Charter of Fundamental Rights and Freedoms when she denied housing to a Roma woman because of her race. ${ }^{1} \mathrm{~A}$ non-governmental organization in the Czech Republic conducted systemic testing of real estate agents to determine if they discriminate against persons of Roma ethnicity. In the course of one test, an agent asked a tester if she was Roma and stated that she would not rent to Roma because of a previous bad experience. Unknown to the agent, the tester recorded the conversation. The tester subsequently sued for damages and an apology.

The trial judge found discrimination and ordered the agent to apologize to the tester. However, the judge refused to award damages to the tester on the ground that the tester should not have been surprised to find discrimination. ${ }^{2}$ Neither party appealed the ruling. ${ }^{3}$

* Michael P. Seng, Professor of Law, The John Marshall Law School, Chicago, Illinois, USA / E-mail: 7seng@jmls.edu

1 Lenka Balogova v. Noskova, Case no. 14 C 46/2013 (District Court, Litomerice, Czech Republic).

2 “RealestateagentmustapologizetoRomaforDiscrimination,"CeskeNoviny(14August2015)http://www.ceskenoviny.cz/zpravy/real-estate-agent-must-apologise-to-romany-for-discrimination/1247591; Prague Daily Monitor http://www.praguemonitor.com/2015/08/17/real-estate-agent-must-apologise-roma-discrimination.

3 “Real estate agent to apologise for discrimination," Prague Daily Monitor (3 December 2015) http:// praguemonitor.com/2015/12/03/real-estate-agent-apologise-discrimination 
There is a history of discrimination against Roma in Europe just as there is a history of discrimination against African Americans in the United States. ${ }^{4}$ The similarities and differences can be debated, but there is a commonality in the methods used to prove and remedy individual acts of discrimination in both contexts. Since the United States Supreme Court's decision in Brown v. Board of Education ${ }^{5}$ there has been a concerted effort in the United States to confront and make illegal various forms of racial as well as other class-based discrimination against discreet and insular minorities. Likewise since the Nazi experience in the $1930 \mathrm{~s}$ and 40 s, where Jews, Roma, and other disfavored groups were singled out for extermination, European nations have recognized that the law can be useful in fighting discrimination. ${ }^{6}$ One of the specific recommendations of Human Rights Watch in its report on Czech Roma in 1996 was that the Czech government should "abide by its obligations under international law to respect and promote human rights and specifically to... [e]nsure that Roma are not treated in a discriminatory manner with regard to access to housing." 7 This recommendation is still a challenge to the Czech government. ${ }^{8}$

The finding of discrimination made by the trial court in Litomerice was similar to what would have been found by a court in the United States. However, there are differences. In some states in the United States it is illegal to record conversations without the consent of all parties. ${ }^{9}$ In other states, it is legal to record a conversation with the consent of only one party. ${ }^{10}$ Therefore, depending upon the particular American jurisdiction, the tape recordings made during the testing exercise may or may not have been admissible as evidence against the real estate agent.

Also, American statutes and case law would have supported an award of compensatory damages, and possibly punitive damages, against the agent to make whole the tester and

4 Discrimination against Roma in the Czech Republic is well documented. See "New plan for Czech ghettos aims to combat dodgy landlords," Prague Radio (28 July 2016) http://www.czech.cz/en/Vie-Travail/New-plan-for-Czech-ghettos-aims-to-combat-dodgy-la; "Czech Republic: Must Try HarderEthnic Discrimination of Romani Children in Czech Schools,” Amnesty Int'l (23 April 2015) https:// www.amnesty.org/en/documents/eur71/1353/2015/en/; "Roma in the Czech Republic - Foreigners in Their Own Land," Human Rights Watch (June 1996) https://www.hrw.org/legacy/reports/1996/ Czech.htm; Fonseca, Bury Me Standing: The Gypsies and their Journey (1995).

5347 U.S. 483 (1954).

6 European Convention on Human Rights, Article 14.

7 "Roma in the Czech Republic - Foreigners in Their Own Land," Human Rights Watch, pp. 2-3 (June 1996) https://www.hrw.org/legacy/reports/1996/Czech.htm

8 "New plan for Czech ghettos aims to combat dodgy landlords," Prague Radio (28 July 2016). http:// www.czech.cz/en/Vie-Travail/New-plan-for-Czech-ghettos-aims-to-combat-dodgy-la

9 A typical example is the Illinois Eavesdropping Act, 720 ILCS 5/14, which makes it illegal to record a conversation without the consent of all parties to the conversation.

10 For instance in Wisconsin, it is legal to record a conversation if only one party consents, in this case consent would be given by the tester who is recording the conversation. Wis. Stat. $\int 968.31$ (2)(c). 
to deter future illegal conduct by this defendant and other similarly situated housing providers. As stated by the United States Supreme Court in the context of standing to sue: "A tester who has been the object of a misrepresentation under $\int 804$ (d) [misrepresentation as to the availability of a dwelling] has suffered injury in precisely the form the statute was intended to guard against, and therefore has standing to maintain a claim for damages under the Act's provision. That the tester may have approached the real estate agent fully expecting he would receive false information, and without any intention of buying or renting a home, does not negate the simple fact of injury within the meaning of $\int 804(\mathrm{~d}) .{ }^{\prime 11}$

American courts, including the United States Supreme Court, explicitly sanction testing as a means to detect housing discrimination. ${ }^{12}$ American courts recognize that testing is the best, and sometimes the only, way to prove discrimination. Testing is when two persons who are equivalent in every way except the protected classification apply for housing to see if they are treated the same. If they are treated differently, the only reasonable explanation is that they were denied housing because of the prohibited characteristic. The burden of proof thus shifts to the housing provider to show the absence of illegal discrimination. Often complaints of housing discrimination disappear after a valid test where it is demonstrated that the landlord treated all applicants the same. Testing is done not only by civil rights and fair housing enforcement agencies, it is sometimes used by real estate companies and lenders to determine if their agents are following the law.

This article will explain how American law prohibits housing discrimination and how testing is used in the United States to enforce the law. The American experience is not so different from the European experience so a knowledge of American law may be helpful to European courts and policy makers in ensuring that all persons have access to equal and decent housing.

\section{Housing discrimination is illegal in the United States}

Housing discrimination was and continues to be a major social and legal problem in the United States. ${ }^{13}$ Since 1968, it has been illegal under federal law in the United States to discriminate in housing transactions based on a person's protected status. ${ }^{14}$ Even prior to 1968 , some states and local governments had enacted laws making discrimination

11 Havens Realty Corp. v. Coleman, 455 U.S. 363, 373-374 (1982).

12 Gladstone Realtors v. Village of Bellwood, 441 U.S. 91 (1979); Havens Realty Corp. v. Coleman, 455 U.S. 363 (1982).

13 Massey and Denton, "American Apartheid, Segregation and the Making of the Underclass (1993); Yinger, Closed Doors, Opportunities Lost, The Continuing Costs of Housing Discrimination" (1995); Squires and Kubrin, Privileged Places: Race, Residence, the Structure of Opportunity (2006); Duneier, Ghetto: The Invention of a Place, the History of an Idea" (2016).

14 The Fair Housing Act, as amended, 42 U.S.C. $\$ 3601$ et seq. 
in the sale or rental of housing illegal. ${ }^{15}$ Just as an employer cannot discriminate in the employment context or a hotel or restaurant proprietor cannot discriminate in access to public accommodations or officials cannot discriminate in access to governmental programs and services, housing providers, whether public or private, cannot discriminate in the access of housing. ${ }^{16}$ In the Civil Rights Act of 1866, Congress had provided that everyone is to be free of racial discrimination in the right to inherit, purchase, lease, sell, hold and convey real and personal property. ${ }^{17}$ However, this very first civil rights law enacted following the Civil War and the emancipation of the slaves was not fully enforced for 102 years. It was not until 1968 that the United States Supreme Court interpreted the 1866 Act to prohibit refusals to sell private property because of the race of the buyer. ${ }^{18}$ That same year Congress passed the more comprehensive Fair Housing Act. ${ }^{19}$

The Fair Housing Act prohibits more discrimination than simply racial discrimination. Seven protected classes are enumerated in the Fair Housing Act as it currently stands. Today, the Fair Housing Act protects the following classes: race, color, religion, sex, familial status, national origin, and handicap. As originally passed in 1968, the statute prohibited only discrimination on the basis of race, color, national origin, and religion. Congress added sex discrimination in 1974. The Amendment has been construed to cover cases

15 A good example is California, which prohibited housing discrimination before it was illegal under federal law. A state referendum amended the California Constitution to repeal these laws by giving residents of California a state constitutional right to discriminate. One year before the passage of the federal Fair Housing Act, the United States Supreme Court held this state constitutional provision to be illegal state action supporting discrimination under the Fourteenth Amendment to the United States Constitution. Reitman v. Mulkey, 387 U.S. 369 (1967).

16 The Fair Housing Act applies only to "dwellings" and contains a number of exemptions, such as owner occupied buildings with no more than four units, certain sales of individual homes when the services of a broker are not utilized, and some housing provided by religions and private clubs. A "dwelling" has been defined as "a temporary or permanent dwelling place, abode or habitation to which one intends to return as distinguished from the place of temporary sojourn or transient visit." 42 U.S.C. \3602(b). United States v. Hughes Memorial Home, 396 F. Supp. 544 (W.D. Va. 1975).

1742 U.S.C. $\int 1982$.

18 Jones v. Alfred H. Mayer Co., 392 U.S. 409, 442-443 (1968), where the Supreme Court held that Congress had power to pass the law under the Thirteenth Amendment as a means of abolishing the badges and incidents of slavery. The Court stated that "[W] hen racial discrimination herds men into ghettos and makes their ability to buy property turn on the color of their skin, then it too is a relic of slavery."

1942 U.S.C. $\int 3601$ et seq. Complaints can still be filed under the Civil Rights Act of 1866. The 1866 Act is both broader and narrower than the Fair Housing Act. The Act is broader than the Fair Housing Act because it covers all property, real and personal, and not just "dwellings." It is narrower than the Fair Housing Act because it only covers racial discrimination. Because it adopts the $19^{\text {th }}$ Century view of race, which is broader than our more color based approach today, the Civil Rights Act covers some forms of present day national origin discrimination. Saint Francis College v. Al-Khazzaji, 481 U.S. 604 (1987) (discrimination against Arabs); Shaare Tefila Congregaton v. Cobb, 481 U.S. 615 (1987) (discrimination against Jews.).

Persons suing under the 1866 Act can get compensatory and punitive damages as well as equitable relief. Sullivan v Little Hunting Park, Inc., 396 U.S. 229, 238-40 (1969); Phiffer v Proud Parrot Motor Hotel, Inc., 648 F.2d 548, 553 (9th Cir. 1980).

The statute can be enforced in both state and federal court. It has no administrative remedy. 
of sexual harassment whether based on quid pro quo or hostile environment theories. ${ }^{20}$ The Act has also been construed to cover domestic abuse. ${ }^{21}$ While the amendment does not explicitly cover discrimination based on sexual orientation, HUD rules prohibit discrimination based on sexual orientation in federally subsidized housing programs. ${ }^{22}$ Where same-sex couples are applying for housing, a good argument can be made that a denial based on the sex of one of the partners is discrimination because of sex.

The 1988 Fair Housing Amendments Act added discrimination on the basis of handicap and against families with children and expanded enforcement and remedies. Neither persons with disabilities ${ }^{23}$ nor families with children ${ }^{24}$ had been interpreted to be suspect classifications under the Equal Protection Clause of the Fourteenth Amendment to the United States Constitution, so their inclusion in the Fair Housing Act was significant.

Familial status is defined under the 1988 Amendments Act as persons having legal custody, or their designees, of an individual under the age of 18 years. ${ }^{25}$ It includes preg-

20 Shellhammer v. Lewallen, 1 FH/FL $\$ 15,472$ (N.D. Ohio 1983); Woods v. Foster, 884 F.Supp. 1169 (N.D, Ill, 1995); Reeves v. Carrollsburg Condominium, FH/FL 『16,250 (D.C. 1997).

21 HUD Memorandum, Assessing Claims of Housing Discrimination against Victims of Domestic Violence under the Fair Housing Act and the Violence Against Women Act (Feb. 9, 2011) http://hud.gov/ offices/fheo/library/11-domestic-violence-memo-with-attachment.pdf

22 Final Rule, Equal Access to Housing in HUD Programs Regardless of Sexual Orientation or Sexual Identity, 77 Fed. Reg. 5662 (2012).

23 The Supreme Court has held that discrimination against persons with disabilities is not suspect because there is no history or pattern of irrational state discrimination against persons with disabilities. Cleburne v. Cleburne Living Center, 473 U.S. 432 (1985). Therefore, states have no constitutional duty to provide special accommodations for persons with disabilities so long as their decisions are rational. Board of Trustees v. Garrett, 531 U.S. 356 (2001).

24 The Supreme Court did hold in Moore v. City of East Cleveland, 431 U.S. 494 (1977), that a city violated Due Process when it enforced an ordinance that prohibited "close" relatives, who were related by blood, from living together in the same household.

2542 U.S.C. $\int 3602(\mathrm{k})$. Housing providers cannot impose restrictions on families with children that are not generally applicable to everyone. 24 CFR S 100.65(b)(4). Similarly, families with children cannot be denied access to recreational or other facilities and services that are made available to other tenants. A good example is Fair Housing Congress v. Weber, 993 F. Supp. 1286, 1290-3 (C.D.Cal. 1997), which held that families with children cannot be barred from upper floors because of safety fears for the children. Rules that restrict young children from a utility room or a swimming pool without an accompanying adult have been upheld in some cases. HUD v. Guglielmi, FH/FL -25,076 at page 25,076 (HUD ALJ 1990) (utility room); HUD v. Murphy, FH/FL $\mid 25,002$ at page 25,053 (HUD ALJ 1990) (swimming pool). However, those rules have to be justified and many cases have found restrictions on children in common areas to be illegal. In most cases, judges have said that it is up to the parents to determine what risks are appropriate for their children. United States v. Grishman, 818 F. Supp. 21 (D. Me. 1993) (housing provider cannot refuse to rent house on a rocky ocean cliff because of concerns of danger to children); HUD v. Schmid, FH/FL 925,139 (HUD ALJ 1999) (swimming pool). Normally each case must be examined individually and one cannot draw stereotypes about all children. HUD v. Colclasure, FH/FL -26,109 (HUD ALJ 1998) (landlord cannot assume that children will cause additional wear and tear on the unit). Case law holds that housing providers cannot assume that children will misbehave. Therefore, it is better to prohibit the conduct generally. See, HUD v. Jeffre, FH/FL $-25,020$ (1991) (housing provider cannot assume that minor children will cause problems). Of course, if a child becomes unruly or causes serious problems, housing providers may refuse to deal with that tenant the same as they would with any unruly tenant. 
nant women or someone in the process of securing legal custody of a child. ${ }^{26}$ It does not apply in marital status cases. The provision protects foster families. ${ }^{27}$ The Act exempts housing for older persons from the familial status prohibitions. ${ }^{28}$ This exemption is narrowly construed and does not permit senior housing to discriminate on any other ground prohibited by the Act.

The definition of a handicapped person under the Fair Housing Act is borrowed from the Rehabilitation Act of $1973 .{ }^{29}$ A handicap is defined as:

Someone with a physical or mental impairment which substantially limits one or more major life activities;

Someone with a record of an impairment; or Someone who is regarded as having an impairment. ${ }^{30}$

The 1988 Amendments state that reasonable occupancy requirements are permitted. HUD has wrestled with the question of what is a reasonable occupancy standard. The question most frequently comes in cases involving familial status discrimination, but it can involve other classes as well. The current standard is that the so-called Keating Memo, http://www.hud.gov/offices/fheo/library/occupancystds.pdf, which generally approves a two person per bedroom standard, but which also allows for some flexibility depending upon the particulars of the premises. A municipality that imposes an occupancy standard carries the burden of establishing that it is reasonable and is not entitled to a presumption of validity. Fair Housing Advocates v. City of Richmond Heights, 209 F.3d 626 (6th Cir. 2000) (holding that a restriction based on square footage was not unreasonable and was within the discretion of the municipality). Restricting occupancy in a one bedroom unit to one person violates the Fair Housing Act. United States v. Badgett, 976 F.2d 1176 (8th Cir. 1992). However, in Sierra v. City of New York, 579 F. Supp. 2d 543 (S.D.N.Y. 2008), the court upheld a restriction on children under 16 living in single room occupancy (SRO) units operated by the City when the units lacked in-unit kitchens or bathroom facilities. The Court accepted the City's argument that the restriction was necessary to protect the health and safety of younger children. The Court also rejected the plaintiff's argument that the dangers in a SRO were preferable to those in homeless shelters or on the streets. The Court was not convinced that these alternatives were the only alternatives to a SRO unit. Mountainside Mobile Estates v. HUD, 56 F.3d 1243 (10th Cir. 1995), recognizes that an occupancy standard is legal if the housing provider can demonstrate that the standard has a manifest relationship to the housing in question. In that case, the landlord was able to show that the sewer connection would not accommodate more persons in the unit. If the occupancy standard is used as a pretext for racial or national origin discrimination, it will be illegal. U.S. v. Town of Cicero, 1997 WL 337379 (June 16, 1997).

2642 U.S.C. $\$ 3602(\mathrm{k})$.

27 Gorski v. Troy, 929 F.2d 1183 ( $7^{\text {th }}$ Cir. 1991).

2842 U.S.C. $\$ 3607(\mathrm{~b})(2)$.

2929 U.S.C. $\int 701$ et seq.

3042 U.S.C. $\$ 3602(\mathrm{~h})$. The Act covers all disabled persons and anyone associated with them: family, friends, caregivers, etc. The Act excludes: current, illegal users of drugs, but recovering drug addicts who are no longer taking drugs are considered disabled persons; persons with infectious diseases; persons who create a "direct threat" to the health and safety of others. "Direct threat" must be established by objective evidence of overt acts that caused harm or threatened harm. Wirtz Realty Corp. v. Freund (Ill. App. 1999) FH/FL para. 18, 262.

A person whose impairment can be corrected by medication or corrective devises may not be "handicapped" under the Fair Housing Act. Sutton v. United Airlines, 527 U.S. 471 (1999) (ADA); Murphy v. United Parcel Service, 527 U.S. 516 (1999) (ADA). A person must show that a disability has a major impact on that person's ability to perform activities that are of "central importance to daily life." The impairment must be permanent or long-term. Toyota Motor Mfgr. v. Williams, 534 U.S. 184 (2002). 
The handicap provisions of the 1988 Act require housing providers to make reasonable accommodations and allow reasonable modifications for disabled persons. ${ }^{31}$ The failure to accommodate is an independent basis for liability under the fair housing laws. ${ }^{32}$

The Fair Housing Act prohibits a variety of practices. Section 3604(a), prohibits refusals to sell or rent, refusals to negotiate, or any other act to make housing unavailable because of discrimination against a protected class. Subsection 3604(a) has been broadly applied to discrimination by insurance companies that refuse to write insurance in minority neighborhoods or that otherwise discriminate on the basis of a protected class. ${ }^{33}$ Subsection (b) prohibits discrimination in the terms, conditions, or privileges of sale or rental, or in services or facilities.

One of the most important restrictions in the Fair Housing Act is subsection (c) that makes it unlawful to publish any discriminatory notice, statement, or advertisement. This subsection is very important because the exemptions in the Act do not apply and the subsection imposes virtual strict liability for one who publishes a discriminatory statement. Subsection (d) makes it illegal to represent that a dwelling is not available, and subsection (e) prohibits blockbusting.

Section 3605 has been important in recent years because it prohibits discrimination in residential real estate transactions, which applies to discrimination in home residential lending and other forms of financial assistance. Beginning with the Justice Department

3142 U.S.C. $\int 3604(\mathrm{f})(3)$ (A) and (B).

32 See, Wisconsin Community Services, Inc. v. City of Milwaukee, 465 F.3d 737 (7 $7^{\text {th }}$ Cir. 2006). Reasonable accommodations are required when necessary to afford equal opportunity to use and enjoy a dwelling unless doing so would "impose undue financial or administrative burdens" or require a "substantial" or "fundamental alteration" in the existing regulatory scheme. Landlords are required to allow tenants to make reasonable modifications to the premises when necessary to afford the full enjoyment of the property, but they can require that the modifications be done in a workmanlike manner, and the landlord may demand that the premises be returned to their original condition once the tenancy is terminated if this is reasonable. The tenant may be required to establish an escrow account to ensure that restoration will be accomplished. The Act contemplates that most questions concerning reasonable accommodations and modifications will be resolved through good faith bargaining between the housing provider and the tenant. Courts are reluctant to allow damage actions against a defendant who has set up reasonable procedures to resolve a request for an accommodation. Adam v. Linn-Benton Housing Authority, 147 F. Supp. 2d 1044 (D. Ore. 2001).

The Act further requires that new multi-family housing of four or more units meet certain accessibility requirements. 42 U.S.C. \$ 3604(f) (3) (C). These requirements are relatively simple and inexpensive to meet if they are incorporated in the original design of the building. However, housing developers and architects have been slow in complying with these requirements. The legislative history is clear that Congress did not intend to establish a national building code. HUD may encourage, but not require, states and local governments to enforce design and construction requirements that are at least as stringent as the requirements in the Act. However, the Act does not require either HUD or state or local building officials to review or approve the plans, designs, or construction of covered multifamily dwellings to see whether they conform to the Act.

33 E.g., NAACP v. American Family Mutual Insurance Co., 978 F.2d 287 ( $7^{\text {th }}$ Cir. 1992), cert denied, 508 U.S. 907 (1993). 
consent decree against Decatur Federal in $1992,{ }^{34}$ there have been a number of successful cases filed against the mortgage lending industry that have resulted in major changes in lending practices and substantial damages awarded to victims of mortgage lending discrimination. Section 3605 also applies to predatory loans that are targeted against classes protected by the Fair Housing Act. ${ }^{35}$

Section 3606 prohibits discrimination in providing brokerage services. Section 3617 makes it illegal to interfere, threaten, or coerce persons in the exercise of their fair housing rights. This section has raised free speech concerns when the activities involve petitioning the government or the filing of law suits. ${ }^{36}$

The 1988 Amendments Act expanded enforcement of the 1968 Fair Housing Act beyond private civil suits for damages or injunctive relief. ${ }^{37}$ Complainants have the option to file a complaint with the United States Department of Housing and Urban Development (HUD).$^{38}$ HUD has a mandate to investigate complaints filed with that agency within 100 days and to seek conciliation of fair housing claims. If HUD finds reasonable cause that a violation has occurred, the parties may elect to have the case tried by a HUD administrative law judge or in the courts. The United States Department of Justice has power to bring enforcement actions in pattern and practice cases. ${ }^{39}$ The 1988 Act allows recover equitable and damage relief, we well as punitive damages (except in administrative proceedings). It further allows for the award of attorneys' fees to prevailing complainants. HUD also has power to issue regulations to enforce fair housing, which HUD has done and which are very useful to those seeking guidance about the requirements of the Act. ${ }^{40}$

The Fair Housing Act also recognized that state and local laws play a substantial role in preventing housing discrimination. States and local governments that pass laws and ordinances that are substantially equivalent to the federal Act may receive federal funding

34 Https://www.justice.gov/crt/housing-and-civil-enforcement-cases-documents-287

35 See, Barkley v. Olympia Mortgage Co., 2007 WL 2437810 (E.D.N.Y. 2007); Honorable v. Easy Life Realty, 100 F. Supp. 2d 885 (N.D. Ill. 2000); Hargraves v. Capital City Mortgage, 140 F. Supp. 2d 7 (D.D.C. 2000); Eva v. Midwest National Mortgage Bank, Inc., 143 F. Supp. 2d 862 (N.D. Ohio 2001); Beard v. Worldwide Mortgage Corp., 354 F.Supp.2d 789 (W.D.Tenn. 2005).

36 A federal appeals court in California has held HUD investigators liable for unlawfully pursuing an investigation into the activities of a neighborhood group that had filed a lawsuit in state court and petitioned a local government to stop a group home from moving into the neighborhood. White v. Lee, 227 F.3d 1214 ( $9^{\text {th }}$ Cir. 2000). The Supreme Court has held that a state may validly prosecute someone who burns a cross intentionally to intimidate a racial minority from moving into the neighborhood. Virginia v. Black, 538 U.S. 343 (2007).

3742 U.S.C. $\int 3613$.

3842 U.S.C. $\int 3610$.

3942 U.S.C. $\int 3614$.

4042 U.S.C. S 3614a. 
to assist in their enforcement efforts. ${ }^{41}$ Many state and local governments have sought and gained substantial equivalency. Also, state and local laws can provide more protection than the federal Act, and many state and local laws provide more protection than the federal Act. For instance, some local laws prohibit discrimination on the basis of sexual orientation or preference, marital status, age, source of income, and veteran's status, and also have narrower exemptions than the federal law.

\section{Why housing discrimination is important - damage caused}

Even today, nearly fifty years after the American Congress passed the Fair Housing Act, discrimination against all protected classes still occurs in the United States, and American cities continue to be segregated on the basis of race. ${ }^{42}$ The struggle for equal rights in the ownership of property began immediately after the abolition of slavery, but until 1968, tools to abolish private discrimination in housing did not exist. Private discrimination, often in the form of restrictive covenants that explicitly discriminated on the basis of race, ${ }^{43}$ as well as many federal, state and local governmental laws and policies promoted racial segregation. Discriminatory lending practices restricted where persons could buy homes. The results of those policies are evident in America's cities today.

In addition to "when racial discrimination herds men into ghettos," discrimination in housing causes real damage to the victims of discrimination. Segregation affects employment and educational opportunities, public health, life expectancy, law enforcement, and the accumulation of wealth - in other words, nearly all aspects of life in the United States. ${ }^{45}$ It subjects victims of discrimination to humiliation and embarrassment and

4142 U.S.C. $\int 3616$.

42 This was recently acknowledged by the United States Supreme Court in Texas Department of Housing v. Inclusive Communities, 135 S.Ct. 2507 (2015). Numerous studies document the extent of housing discrimination in the United States. Massey and Denton, "American Apartheid, Segregation and the Making of the Underclass (1993); Yinger, Closed Doors, Opportunities Lost, The Continuing Costs of Housing Discrimination (1995); Squires and Kubrin, Privileged Places: Race, Residence, the Structure of Opportunity (2006); Duneier, Ghetto: The Invention of a Place, the History of an Idea" (2016).

43 Shelley v. Kraemer, 334 U.S. 1 (1948), held that courts could not enforce restrictive covenants under the Fourteenth Amendment. However, they continued by private agreement until at least 1968.

44 Jones v. Alfred H. Mayer, 392 U.S. 409, 442-43 (1968). And see Duneier, Ghetto: The Invention of a Place, the History of an Idea (2016); Satter, Family Properties (2009).

45 Lipsitz \& Oliver, "Integration, Segregation, and the Racial Wealth Gap," in The Integration Debate, (Hartman and Squires, editors, 2010); Alexander, The New Jim Crow: Mass Incarceration in the Age of Colorblindness (2010); Lipsitz, The Possessive Investment in Whiteness: How White People Profit from Identity Politics (2006). 
to stresses that affect not only the individual, but whole families and neighborhoods. ${ }^{46}$ It offends human dignity in its most elemental form.

Discrimination also causes damage to the community at large ${ }^{47}$ For this reason, the United States Supreme Court has expanded standing to enforce the Fair Housing Act to community residents and to municipalities that are injured by discriminatory housing practices. ${ }^{48}$ The damage may include increased costs of policing and other municipal services, diminished property values which cause a loss of revenue to local governments that largely rely on property taxes for their revenue, and damage to the ability of municipalities to attract investment and business opportunities. ${ }^{49}$ The loss of human potential alone is incalculable.

\section{Traditional standards of proof}

\subsection{Intentional discrimination}

Discrimination can be established by showing an intention to discriminate or by showing a discriminatory impact.

46 See Lipsitz, How Racism Takes Place (2011); Heifetz and Heinz, Separating the Objective, the Subjective, and the Speculative: Assessing Compensatory Damages in Fair Housing Adjudications, $27 \mathrm{~J}$. Marshall L. Rev. 3 (Fall 1992) http://www.jmls.edu/clinics/fairhousing/pdf/commentary/separating-objective.pdf; Heinrich, The Mental Anguish and Humiliation Suffered by Victims of Housing Discrimination, 27 J. Marshall L. Rev. 39 (Fall 1992) http://www.jmls.edu/clinics/fairhousing/pdf/ commentary/mental-anguish-humiliation.pdf. And see Khazan, "Racial Segregation Is Making Americans Sick," The Atlantic (March 16, 2016) http://www.theatlantic.com/health/archive/2016/03/ racial-segregation-is-making-americans-sick/473943/

47 Massey and Denton, American Apartheid: Segregation and the Making of the Underclass (1993). The classic study that led to the passage of the Fair Housing Act was the Report of the National Advisory Commission on Civil Disorders (The Kerner Report) (1968).

48 Trafficante v. Metropolitan Life Insurance Co., 409 U.S. 205 (1972); Gladstone Realtors v. Village of Bellwood, 441 U.S. 91 (1979).

49 A redlining case was filed by the City of Baltimore against Wells Fargo Bank alleging that its predatory home lending policies in the African American community had increased segregation and caused foreclosures and other economic problems in African American areas of the City, which resulted in damages to the City in lost real estate taxes and other expenses related to communities hurt by the foreclosure crisis. Mayor and City Council of Baltimore v. Wells Fargo Bank, LO8 CV 062 (D. Md., filed Jan. 8, 2008). The suit was ultimately settled. FH/FL 9 (Aug. 1, 2012). Standing of municipalities against lenders who engaged in discriminatory lending has also been upheld in City of Miami v. Bank of America, 800 F.3d $1262\left(11^{\text {th }}\right.$ Cir. 2015) and City of Miami v. Citigroup, 801 F.3d 1268 (11 ${ }^{\text {th }}$ Cir. 2015). A federal district court judge held in County of Cook v. Wells Fargo \& Co., 2015 WL 4397842 (N.D.Ill. 2015), that although Cook County, Illinois had adequately alleged an injury under Article III of the Constitution, it was not within the "zone of interest" to have statutory standing as an "aggrieved person" within the meaning of the Fair Housing Act. The Court particularly focused on the more restrictive language of Section 3605 that governs mortgage lending and held that it protected only persons who were either denied a loan or offered unfavorable loan terms and conditions and that Cook County fell within neither class of plaintiffs that Congress intended to protect. Another district court judge in the Northern District of Illinois has strongly criticized this case and refused to follow it, as did the Court of Appeals for the Eleventh Circuit. County of Cook v. HSBC North America Holdings, 2015 WL 5768575 (N.D.Ill. 2015); City of Miami v. Bank of America, 800 F.3d 1262 (11 ${ }^{\text {th }}$ Cir. 2015). 
Intentional discrimination can be shown by either direct or circumstantial evidence. Direct evidence includes statements, advertisements, regulations or policies that explicitly refer to a protected class. Examples are advertisements that seek "single women only" or that display photos of white residents only or statements by a rental agent that wheel chairs are not allowed in the congregate dining facilities of a senior center. Circumstantial evidence includes the housing provider's rental history, statistics showing the number of residents in protected classes where the nature of the community would assume greater diversity, and the sequence when units were listed or taken off the market.

As in cases involving employment discrimination, courts often employ a disparate treatment framework to analyze whether there is intentional discrimination. ${ }^{50}$ Under the disparate treatment analysis, a prima facie case of discrimination is established by showing that:

The complainant is a member of a protected class;

The complainant applied for the housing and was qualified;

The complainant was rejected and the unit remained available.

This framework can be adjusted to the circumstances. For instance, if the complainant was never allowed to apply, the issue of his or her qualifications is moot. Once the complainant establishes a prima facie case, the burden shifts to the respondent to articulate a legitimate reason not based on the protected status of the complainant. Then complainant can still go forward to show that this reason is a pretext for discrimination. A court may infer discrimination from the falsity of the respondent's explanation. ${ }^{51}$

In the Czech case, the real estate agent defended her refusal to rent to Roma on the ground that she had a previous bad experience with Roma tenants. This type of stereotyping is never acceptable. An acceptable defense might be that the agent has checked the potential tenant's references and learned about a prior history of not paying rent on time, of not keeping the premises clean, of her children creating disturbances, or of any other reason that would show that this person would not be a good tenant. However, one cannot assume that persons of a particular race or ethnic group cause

50 McDonald Douglas Corp. v. Green, 411 U.S. 792, 802 (1973). The Supreme Court has warned that the disparate treatment test should not be confused with the disparate impact test. Therefore, a court may not use a disparate impact analysis in finding that a defendant's neutral policy was not a legitimate nondiscriminatory reason in a disparate treatment case. Raytheon Co. v. Hernandez, 540 U.S. 44 (2003).

51 Reeves v. Sanderson Plumbing Products, Inc., 530 U.S. 133 (2000). The Supreme Court has not decided a mixed motive case in the fair housing context, but it is likely that here to it would use the same analysis that it employs in employment discrimination cases. In its decision involving employment discrimination in Price Waterhouse v. Hopkins, 490 U.S. 228 (1989), the Supreme Court held that in a mixed motive case once the complainant establishes a discriminatory motive, the respondent need show only a non-discriminatory reason for the decision. Congress overturned Price Waterhouse in 1991, but did not mention the Fair Housing Act. HUD ALJ opinions adopt the Price Waterhouse rationale under the Fair Housing Act. See HUD v. Denton (HUD ALJ 1991) FH/FL $\mid 25,014$ and (HUD ALJ 1992) $\uparrow 25,024$. 
problems or that families with children or persons with disabilities will necessary cause damage or disturb the peace and quiet of other residents. ${ }^{52}$

One of the most effective means of proving intentional discrimination is through testing. Indeed, in many cases, testing may be the only means available to show that an individual act was motivated by discrimination. Because testing distinguishes individuals solely on the basis of a prohibited classification such as race it ensures that other factors such as income, occupation, prior rental history or any other legitimate factor that might be considered in renting or selling housing are excluded as a reason for the denial. Testing works both ways. It identifies discrimination when it exists and it also shows when a landlord had a legitimate reason apart from a prohibited classification to refuse a unit.

\subsection{Disparate Impact}

A violation of the Fair Housing Act can also be established by showing that a policy or practice has a discriminatory impact even in the absence of any proof of an intent to discriminate. HUD has adopted the disparate impact theory in its regulations, and this regulation offers powerful support for finding that a rule or policy of either a public housing authority or of a private landlord is illegal because of its disparate impact on a protected class. ${ }^{53}$ The rule puts the burden on the charging party to show a discriminatory effect. Once this burden is satisfied, the burden of proving that the practice is necessary to achieve a substantial, legitimate, nondiscriminatory interest is on the respondent. If the respondent successfully articulates a nondiscriminatory reason, the complainant must show that the respondent's interest could be served by another practice that has a less discriminatory effect. ${ }^{54}$ The rule specifically states that a legally sufficient justification may not be used as a defense against intentional discrimination. ${ }^{55}$

The United States Supreme Court affirmed the disparate impact standard under the Fair Housing Act and the HUD disparate impact rule in Texas Department of Housing and

52 See HUD v. Colclasure, FH/FL -26,109 (HUD ALJ 1998) (landlord cannot assume that children will cause additional wear and tear on the unit).If the problem is bad behavior, the cases generally say that one cannot assume that children will misbehave. HUD v. Jeffre, FH/FL -25,020 (1991) (housing provider cannot assume that minor children will cause problems).

Similarly, the Fair Housing Act allows a landlord to refuse to rent to a person with a disability "whose tenancy would constitute a direct threat to the health or safety of other individuals or whose tenancy would result in substantial physical damage to the property of other." 48 U.S.C. \$ 3604(f)(9). However, a "direct threat" must be established by objective evidence of overt acts that caused harm or threatened harm and not through broad stereotypes. Wirtz Realty Corp. v. Freund (Ill. App. 1999) FH/FL para. 18, 262. And see, Cleburne v. Cleburne Living Center, 473 U.S. 432 (1985) (claim under the equal protection clause of the Fourteenth Amendment).

5324 CFR Part 100, subpart G, \ 100.500.

54 Id. at $\int 100.500(\mathrm{c})$.

55 Id. at $\int 100.500(d)$. 
Community Affairs v. Inclusive Communities Project. ${ }^{56}$ In doing so, the Court recognized the continuing effects of past discrimination and the role of the Fair Housing Act in eliminating those effects.

Disparate impact is proven largely through statistical evidence. Nonetheless, testing evidence may be persuasive to demonstrate the practical impact of a particular policy or practice. As a human matter, judges are naturally reluctant to find discrimination based on statistics alone. Systemic testing that demonstrates the practical effect of a particular policy is very useful in presenting a case of disparate impact. Sometimes the cumulative effect of tests that show that members of a protected class are excluded turns a case into a disparate treatment case because a judge will recognize that a reasonable person should have known that the practical effect of policies that exclude members of a protected class and are unexplainable for any other reason and therefore "intended" to discriminate. ${ }^{57}$

\section{Testing is an established means of proving discrimination}

Testing is one of the best means to detect housing discrimination. ${ }^{58}$ In Richardson $v$. Howard, ${ }^{59}$ the Court of Appeals for the Seventh Circuit stated:

"The evidence provided by testers both benefits unbiased landlords by quickly dispelling false claims of discrimination and is a major resource in society's continuing struggle to eliminate the subtle but deadly poison of racial discrimination. We have discovered no case in which the credibility of testimony provided by a tester has been questioned simply because of the tester's "professional" status. Indeed, tester evidence may well receive more weight because of its source. Testers seem more likely to be careful and dispassionate observers of events which lead to a discrimination suit than individuals who are allegedly being discriminated against."

Testing is exactly what its name implies. One conducts a test to see if housing discrimination is present. Today persons who discriminate, rarely disclose their motivation. Instead they try to disguise their actions. ${ }^{60}$ When properly done, testing can disclose discrimination in prices and services, in unit availability, and in customer treatment.

56135 S.Ct. 2507 (2015).

57 See Village of Arlington Heights v. Metropolitan Housing Development Corporation, 429 U.S. 252, 266 (1977), where the Supreme Court recognized that intentional discrimination can be shown by an impact that should have been apparent to the offender. Testing has also been used in other contexts. See Pager, Marked: Race, Crime, and Finding Work in an Era of Mass Incarceration (2007), describing a comprehensive testing project in Milwaukee that showed the difficulties facing ex-offenders in the job market. An advantage of a finding of intentional discrimination is that it opens the defendant to potential liability for punitive damages under American law.

58 Gladstone Realtors v. Village of Bellwood, 441 U.S. 91 (1979); Havens Realty Corp. v. Coleman, 455 U.S. 363 (1982).

59712 F.2d 319, 321-22 ( $7^{\text {th }}$ Cir. 1983).

60 Zuch v. Hussey, 394 F. Supp. 1028, 1051 (E.D. Mich 1975), aff'd, 547 F.2d 1168 (6 $6^{\text {th }}$ Cir. 1977); Hamilton v. Miller, 477 F.2d 908, 910 n. 1 (10 ${ }^{\text {th }}$ Cir. 1973); Richardson v. Howard, 712 F.2d 319, 321 ( $7^{\text {th }}$ Cir. 1983). 
In the United States, testing is most often done by private fair housing organizations. ${ }^{61}$ Frequently private fair housing organizations are supported by federal, state, or local governmental funding. The purpose of these fair housing organizations is to provide support to persons who have suffered discrimination. The support may be in the form of counseling, providing legal services, providing public education to both housing providers and consumers, and detecting and remedying discriminatory housing practices. Most private fair housing organizations have a testing program. The John Marshall Law School Fair Housing Legal Clinic has been conducting testing in fair housing cases since 1993. ${ }^{62}$ Much of the material in this section is based on the cumulative experience of the Clinic in testing for fair housing violations during that period.

Testing is sometimes done by government agencies for the purpose of enforcing the law. For instance, the United States Department of Justice has a very active testing program and does testing all over the United States. ${ }^{63}$ More often, government agencies contract with private fair housing organizations to do the testing for them. For instance, The John Marshall Law School Fair Housing Legal Support Center and Clinic has contracted with several municipalities in Iowa and elsewhere to conduct multiple tests, and it has an agreement with the Illinois Department of Human Rights to test cases when that agency needs testing to substantiate a charge of discrimination.

Some housing providers and financial institutions do self-testing in order to ensure that their employees are not violating the law by illegally steering customers or engaging in other forms of housing discrimination. When properly undertaken to ensure compliance with the law, self-testing may shield the employer from liability. ${ }^{64}$ Sometimes, housing providers will do their own testing, but more often they will contract with a local fair housing organization to do the testing for them.

There are many different types of tests depending upon the situation. Trained testers contact rental agencies, brokers, or financial institutions posing as persons seeking to rent or purchase a home to determine if there is any evidence of discrimination. Testers are trained in how to behave and what to look for. Training generally is for several hours and often testers are required to do a field test as part of the training. Testers have no relationship to any party in the case nor do they have any personal or economic interest in the matter. They are given an assumed identity and informed of the facts they are to relate in applying for the housing.

61 In addition to testing for enforcement, testing may also be done for research purposes. See Pager, Marked: Race, Crime, and Finding Work in an Era of Mass Incarceration (2007), p. 75-76.

62 Http://www.jmls.edu/clinics/fairhousing/public/

63 Https://www.justice.gov/crt/fair-housing-testing-program-1

6442 U.S.C. $\int 3614-1$ provides that self-testing in lending cases is privileged and may not be obtained or used by any applicant, department of agency in any civil action or investigation under the Fair Housing Act. The purpose of the privilege is to encourage lenders to engage in self-testing. 
Generally a tester knows nothing of the background of the case nor is the tester given more facts than are necessary to conduct the test. This ensures that the tester will not be biased or will not attempt to entrap the housing provider. The test is considered successful whether or not discrimination is found. It is equally gratifying to find out that a housing provider is not discriminating as it is to detect discrimination. Immediately after the test, the tester writes down what happened in the test and then he or she is debriefed by the testing coordinator, who is often a paid worker for the fair housing organization. Testers are paid a small stipend for their work and the pay is not contingent upon the results of the test. If a test discloses discrimination, the tester may later be interviewed by government investigators or called to testify in court or in an administrative hearing.

Testers respect the confidentiality of the process and do not disclose the fact of testing or the test results to anyone other than the test coordinator or when called to testify. The identity of a tester is kept secret except when a case proceeds to litigation.

Testing may be done by only one tester, such as when a tester goes to a number of apartment complexes to determine if they meet the accessibility requirements of the Fair Housing Act. More often paired tests are conducted where two or more testers with roughly the same credentials except for their protected class status are sent to a housing complex to see if they are given the same information or equal treatment. ${ }^{65}$

Some tests are complaint-based. In other words, an African-American home seeker complains to the fair housing organizations that she thinks that she may have been the victim of discrimination. She telephoned for an appointment and was told the unit was available, but when she showed up at the rental office a short time later, the agent appeared to be nervous and told her that no units were any longer available. A white tester and an African-American tester might be sent to the rental office. If the white tester is told that a unit is available and the African-American tester is told that it is not, this is pretty solid evidence of discrimination.

Other tests may be systemic. ${ }^{66}$ Able-bodied and disabled testers may be sent to test the building of a certain landlord who is suspected of discriminating even though no bona fide person with a disability has complained about the complex.

Most often tests are conducted in person by having the testers appear on site, but sometimes testing is conducted over the telephone when specific information is sought or be-

65 In one of the earliest reported testing cases, a white couple was sent to inquire about a home immediate after an African American couple was rejected. The Court found differential treatment. Bush v. Kaim, 297 F. Supp. 151 (N.D.Ohio 1969).

66 For instance, in United States v. Youritan Construction Co. 370 F. Supp. 643 (N.D. Cal. 1973), aff'd in part and remanded as modified, 509 F.2d 623 ( $9^{\text {th }}$ Cir. 1973), a large number of tests were conducted by black and white testers with similar credentials. Systemic tests or audits in the employment context are described in Pager, Marked: Race, Crime, and Finding Work in an Era of Mass Incarceration (2007). 
cause of the nature of the business. For instance, home-owners insurance is most often purchased over the phone rather than by a visit to the insurance agent's office.

The United States Justice Department equips its testers with recording devises. However, some states make it illegal to record a conversation without the permission of all parties to the conversation. ${ }^{67}$ The Justice Department cannot be restricted by state law in its investigation of federal violations and, therefore, the United States can record tests even in those states that make recording illegal. ${ }^{68}$ Private fair housing groups have not challenged these state laws even though the groups are acting as private attorneys general in enforcing federal law. ${ }^{69}$

\section{Testing is legal and ethical}

One of the most frequent objections to testing is that it is unethical. ${ }^{70}$ Critics argue that it is an unfair procedure used to entrap an unwary housing provider. Testers are at best paid liars. While of necessity, testers assume a false identity, there is nothing unethical or illegal about what a tester does. A well-trained tester does not solicit information not freely volunteered by the housing provider. Testers are trained not to suggest to housing providers that they discriminate or to lead a housing provider into making incriminating statements. Testers simply assume an identity and allow that identity to speak for itself. If the landlord treats all applicants equally, the test is termed a success; the same as when the landlord treats applicants differently. Each applicant is unaware of the way the other tester is treated and will generally not ever know for sure if there was discrimination until later called to testify.

67 A typical example is the Illinois Eavesdropping Act, 720 ILCS 5/14. Other states allow the recording if one person has consented. Wis. Stat. \ $968.31(2)(\mathrm{c})$.

68 That states cannot interfere with federal law enforcement is firmly enunciated in the Supremacy Clause of the United States Constitution. Article VI. See, McCulloch v. Maryland, 17 U.S.(4 Wheat.) 316 (1819); Gonzales v. Raich, 545 U.S. 1 (2005); Arizona v. United States, 132 S.Ct. 2492 (2012).

In United States v. Wisconsin, 395 F. Supp. 732 (W.D. Wis. 1975), the court held that a Wisconsin statute which purported to regulate testing conflicted with the Fair Housing Act because it made it difficult or impossible to prove discrimination and "chill[ed] the right to equal housing opportunity." Nor may testing be discouraged through the use of private civil actions intended to intimidate testers. Northside Realty v. Chapman, 411 F. Supp. 1195 (N.D. Ga. 1976). Similarly, testing has been held not to be an illegal search or seizure under the Fourth Amendment. Northside Reality Associates, Inc. v. United States, 605 F. 2d 1348 (5th Cir. 1979).

69 Trafficante v. Metropolitan Life Insurance Co., 409 U.S. 205 (1972).

70 For instance, it is sometimes argued that the American Bar Association's Model Rules of Professional Conduct prohibit an attorney from making false statements to third parties. Rule 4. 1. Further, because many tests are conducted under a lawyer's direction, the lawyer is responsible for the false statements made by the testers. Rule 5.3, https://www.law.cornell.edu/ethics/aba/current/ABA_CODE. HTM\#Rule_4. 1. The ethics of conducting testing for social science research is discussed in Pager, Marked: Race, Crime, and Finding Work in an Era of Mass Incarceration (2007), pp. 76-78. Pager concludes that the unique benefit testing can provide in uncovering discrimination and enforcing civil rights laws justifies its use. 
Courts have recognized that testing is likely to be the best source of evidence of discrimination. ${ }^{71}$ It is frequently used to show a pattern and practice of discrimination. ${ }^{72}$ Federal courts have invalidated state attempts to make testing illegal. ${ }^{73}$

\section{Testers are entitled to recover damages}

The United States Supreme Court has held that testers who themselves are given false information even though the tester may have expected to receive false information have standing to sue for injuries under the Fair Housing Act. $^{74}$ As a practical matter, white testers will normally not have suffered injury on this basis. ${ }^{75}$

It is true that fact-finders may be skeptical that testers suffer any real injury in fact ${ }^{76}$ and may believe that testers feel a sense of satisfaction when they uncover discrimination. ${ }^{77}$ But testers do suffer damage. Testers themselves may testify about their feelings of being exposed to discrimination and the hurt it engenders. ${ }^{78}$ Expert testimony may estab-

71 Richardson v. Howard, 712 F.2d 319 (7 $7^{\text {th }}$ Cir. 1983).

72 United States v. Youritan Construction Co. 370 F. Supp. 643 (N.D. Cal. 1973), aff'd in part and remanded as modified, 509 F.2d 623 (9 $9^{\text {th }}$ Cir. 1973); Northside Realty v. Chapman, 411 F. Supp. 1195 (N.D. Ga. 1976); Northside Reality Associates, Inc. v. United States, 605 F. 2d 1348 (5 $5^{\text {th }}$ Cir. 1979).

73 United States v. Wisconsin, 395 F. Supp. 732 (W.D. Wis. 1975).

74 Havens Reality Corp. v. Coleman, 455 U.S. 363, 374 (1982). The private fair housing organization that did the testing may also have standing to sue if the organization suffered injury by diverting resources or frustration of purpose due to the discrimination. Id.

75 Nur v Blake Development Corp., 655 F. Supp. 158, 162 (N.D. Ind. 1987).

76 See Village of Bellwood v Dwivedi, 895 F.2d 1521, 1526 (7th Cir. 1990), where Judge Posner commented, "The standing of the testers is, as an original matter, dubious. They are investigators, they suffer no harm other than that which they invite in order to make a case against the persons investigated; there is no suggestion in this case that they were paid less to be testers than the opportunity costs of their time. The idea that their legal rights have been invaded seems an arch-formalism."

77 In United States v Balistrieri, 981 F.2d 916, 932 (7th Cir. 1992), the court commented that "In fact, a tester who helps expose discrimination could conceivably experience certain satisfaction in helping to correct wrongful conduct. Some testers could even be pleased with the success of their undercover operation."

78 See Davis v Mansards, 597 F. Supp. 334, $347-48$ (N.D. Ind. 1984) (Court awarded actual damages of $\$ 5,000$ to a female tester who was deeply affected by the rejections of her application and $\$ 2,400$ to her husband because he was less profoundly affected.)

In HUD v Gruzdaitis (HUD ALJ 8/14/98) FH/FL $\mid 25,137$, a case brought by a bona fide victim of housing discrimination, Judge Heinz declared:

"Actual damages in housing discrimination cases may include damages for intangible injuries such as embarrassment, humiliation, and emotional distress caused by the discrimination. Damages for emotional distress may be based on inferences drawn from the circumstances of the case, as well as on testimonial proof. Because emotional injuries are by nature qualitative and difficult to quantify, courts have awarded damages for emotional harm without requiring proof of the actual dollar value of the injury. The amount awarded should make the victim whole

"Racial discrimination strikes at the heart of a person's identity. Race and skin color are immutable characteristics irrelevant to whether someone is qualified to buy or rent housing. As racial discrimination has been unlawful in this country for many years, it is reasonable to expect that a person of color would suffer deep frustration, anger, and humiliation upon experiencing discrimination during a search for housing...." 
lish the real harm that exposure to discrimination causes to all persons. ${ }^{79}$ Also, the more blatant the discrimination and harmful the conduct the more likely it is that a fact finder will infer damage and award a large amount of money even to a tester who went into the test knowing that discrimination could be the result. ${ }^{80}$ Triers of fact will recognize that even the strongest individuals cannot always steel themselves from the injury that discrimination causes. ${ }^{81}$ Nevertheless, in most cases, a tester will not be the complainant but only the witness in the case.

Furthermore, in the United States, punitive damages, which are not awarded because of the harm caused to the victim but because of the seriousness of the defendant's conduct, may be awarded to deter the conduct and to send a message to others that discrimination is not tolerated. Substantial damage awards also encourage others who have been injured by housing discrimination to come forward, something many persons are reluctant to do. ${ }^{82}$

The Czech judge who refused to award damages to the tester failed to appreciate the importance of damage awards in compensating persons for their injuries and in deterring such misconduct in the future. However, the Czech judge's reaction to the request for damages was quite normal. Why should the law compensate persons who

79 However, expert testimony to support emotional distress is not required. Damage can be inferred by the fact finder from the testimony of the victim or from the circumstances. Human Rights Commission v. LaBrie (Vt. 10/6/95) FH/FL 918,173; Krueger v. Cuomo, 115 F.3d 487, 492 (7th Cir. 1997); Johnson v Hale, 940 F. 2d 1192 (9th Cir. 1991). In Thornton v. Garcini, 237 Ill. 2d 100 (2009), the Illinois Supreme Court held that expert testimony is not required to support a claim for negligent infliction of emotional distress. The Court observed, "Based on personal experience alone, the jury could reasonably find that the circumstances of this case caused plaintiff emotional distress." Testimony by family members, co-workers and others that observed the plaintiff before and after the discriminatory acts can support a damage award.

80 In Krueger v. Cuomo, 115 F.3d 487, 492 (7th Cir. 1997), the court recognized that: "The more inherently degrading or humiliating the defendant's action is, the more reasonable it is to infer that a person would suffer humiliation or distress from that action; consequently, somewhat more conclusory evidence of emotional distress will be acceptable to support an award for emotional damages, " quoting U.S. v Balestrieri, 981 F.2d 916, 932 (7th Cir. 1992).

81 Specific testimony on the humiliation and burn-out suffered by testers will be crucial to recover substantial compensatory damages. See Davis v Mansards, 597 F. Supp. 334, 347-48 (N.D. Ind. 1984) (Court awarded actual damages of $\$ 5,000$ to a female tester who was deeply affected by the rejections of her application and $\$ 2,400$ to her husband because he was less affected.).

82 In Chicago v Matchmaker Real Estate, No. 88 C 9695, the magistrate awarded \$1,000 to each tester as punitive damages. This award was affirmed in part by the Court of Appeals. Chicago v Matchmaker Real Estate, 982 F.2d 1086, 1099 (7th Cir.1992), cert. denied, 113 S.Ct. 2961 (1993). Davis v Mansards, 597 F. Supp. 334, 347 (1984) (same). This was based on defendants' willful conduct. In United States v Balistrieri, 981 F.2d 916 (7th Cir. 1992), the court affirmed an award of \$2,000 for emotional distress to each tester.

However, a court must not consider the effect of the defendant's conduct on other non-parties. In Philip Morris USA v. Williams, 549 U.S. 346 (2007), the United States Supreme Court held that it violates procedural due process for a court to permit a jury to base a punitive damage award in part upon its desire to punish the defendant for harming persons who are not before the court. 
put themselves in a position to be injured? Nonetheless, testers perform an important public service in helping to document discrimination, and they do suffer trauma each time it is brought home to them that they themselves are not equal to others who are similarly situated except for an immutable characteristic. Attorneys who represent testers as complainants should be aware of this natural reaction against testers and be prepared to offer evidence, even expert testimony when necessary, to show that testers do suffer trauma as a result of their work and deserve to be compensated. Indeed, it is doubtful if there is anyway testers can prepare themselves to prevent injury when discrimination strikes at the very essence of who they are. It is the complainant's attorney who bears the burden of establishing and proving damages. The attorney should never lose sight of this responsibility and provide the judge or fact-finder with the ammunition to sustain a large damage award.

\section{Conclusion}

Housing discrimination causes great damage to both its immediate victims and to the community at large. In this day of ever more sophisticated marketing and sales, cases of blatant facial discrimination still occur, but they account for only a small percentage of legal violations. Once segregated housing patterns are established they are very difficult to eradicate. The experience in the United States demonstrates that it may take generations to eliminate the effects of discrimination and the segregated housing patterns discrimination produces. Both the government and the private sector must be diligent and proactive in combatting this societal cancer. Testing has proven to be one of the most effective means of identifying discrimination so that both private individuals and the government can aggressively combat it. Consequently, testing for housing discrimination should be encouraged, and when testers sue, they should be awarded damages on the same basis as bona fide complainants. 